\title{
Next-Generation Sequencing-Based Detection of Common Bean Viruses in Wild Plants from Tanzania and Their Mechanical Transmission to Common Bean Plants
}

\author{
Beatrice Mwaipopo, ${ }^{1,2}$ Minna-Liisa Rajamäki, ${ }^{3, \dagger}$ Neema Ngowi, ${ }^{1}$ Susan Nchimbi-Msolla, ${ }^{2}$ Paul J. R. Njau, ${ }^{2}$ Jari P. T. Valkonen, ${ }^{3}$ \\ and Deusdedith R. Mbanzibwa ${ }^{1, \dagger}$ \\ ${ }^{1}$ Disease Control Unit, Tanzania Agricultural Research Institute - Mikocheni Centre, Dar es Salaam, Tanzania \\ ${ }^{2}$ Department of Crop Science and Horticulture, Sokoine University of Agriculture, Morogoro, Tanzania \\ ${ }^{3}$ Department of Agricultural Sciences, University of Helsinki, Helsinki, Finland
}

\begin{abstract}
Viral diseases are a major threat for common bean production. According to recent surveys, $>15$ different viruses belonging to 11 genera were shown to infect common bean (Phaseolus vulgaris L.) in Tanzania. Virus management requires an understanding of how viruses survive from one season to the next. During this study, we explored the possibility that alternative host plants have a central role in the survival of common bean viruses. We used next-generation sequencing (NGS) techniques to sequence virus-derived small interfering RNAs together with conventional reverse-transcription PCRs (RT-PCRs) to detect viruses in wild plants. Leaf samples for RNA extraction and NGS were collected from 1,430 wild plants around and within common bean fields in four agricultural zones in Tanzania. At least partial genome sequences

virus diversity was detected in the eastern and northern zones, whereas wild plants in the Lake zone and especially in the southern highlands zone showed only a few viruses. The RT-PCR analysis of all collected plant samples confirmed the presence of yam bean mosaic virus and peanut mottle virus in wild legume plants. Of all viruses detected, only two viruses, cucumber mosaic virus and a novel bromovirus related to cowpea chlorotic mottle virus and brome mosaic virus, were mechanically transmitted from wild plants to common bean plants. The data generated during this study are crucial for the development of viral disease management strategies and predicting crop viral disease outbreaks in different agricultural regions in Tanzania and beyond.
\end{abstract} of viruses potentially belonging to 25 genera were detected. The greatest
Keywords: NGS, Phaseolus vulgaris, plant virus, wild plants
Viruses are obligate parasites that are dependent on their hosts; therefore, viruses that infect annual crop plants require alternate hosts for their survival during the offseason. Otherwise, other means of transmission, such as through seeds, are required (Morales and Castaño 1987). One crop that is infected by many viruses is the common bean, and it has been demonstrated that wild plants may harbor some of its viruses during the offseason (Njau and Lyimo 2000; Sengooba et al. 1997; Spence and Walkey 1995).

Many studies have explored the occurrence of viruses in wild plants and their transmission to the crops of economic importance in which they cause diseases (Njau and Lyimo 2000; Prendeville et al. 2012; Susi et al. 2019; Tugume et al. 2008). Viruses have been detected using enzyme-linked immunosorbent assays (ELISA) and/ or reverse-transcription polymerase chain reaction (RT-PCR); however, RT-PCR is more sensitive than ELISA. Because most of these studies have relied on ELISA, it is likely that the number of viruses detected in wild plants has been largely underestimated (Prendeville

${ }^{\dagger}$ Corresponding authors: M.-L. Rajamäki; minna.rajamaki@helsinki.fi, and D. R. Mbanzibwa; mbanzibwad@yahoo.co.uk

Funding: We acknowledge the Bill and Melinda Gates Foundation and the Government of Tanzania for financial support to Dr. Deusdedith Mbanzibwa through the Program for Emerging Agricultural Research Leaders (PEARL; contract ID OPP1112522). We acknowledge financial support from the Bill and Melinda Gates Foundation (NextGen Phytosanitation) and the Helsinki Institute of Life Science (grant 797011042) to J.P.T. Valkonen.

*The $\boldsymbol{e}$-Xtra logo stands for "electronic extra" and indicates there are supplementary materials published online.

The author(s) declare no conflict of interest.

Accepted for publication 8 January 2021.

Copyright $\odot 2021$ The Author(s). This is an open access article distributed under the CC BY 4.0 International license. et al. 2012). Although RT-PCR is more sensitive than ELISA, its application for the detection of multiple unknown viruses is limited by the fact that prior knowledge of viral sequences is required. Using RT-PCR and ELISA for virus detection in wild plants can be even more challenging because there are no guidelines or protocols to detect viruses in most wild plants (Lacroix et al. 2016). Therefore, it is not easy to detect viruses in crop plants (e.g., common bean) and determine whether the same viruses are harbored in wild plants around the crop fields. The advent of next-generation sequencing (NGS) techniques, however, has made it possible to detect both known and previously unknown viruses in crops and wild plants simultaneously (Kreuze et al. 2009; Susi et al. 2019). This technique has been used to detect viruses in crop plants in Tanzania (Alicai et al. 2016; Mbanzibwa et al. 2014; Mwaipopo et al. 2018; Nordenstedt et al. 2017); however, it has not been used to explore viruses in wild plants in this country.

East Africa is a hotspot for virus diversity, including viruses that infect crops (Ndunguru et al. 2005). Studies of alternate hosts of viruses in wild plants in the region have been performed, but only for some predefined viruses (Amisse et al. 2019; Sydänmetsä and Mbanzibwa 2016; Tugume et al. 2008). Those analyses have indicated that a single virus species may be hosted by many alternate hosts, as in the case of sweet potato feathery mottle virus (SPFMV) (Tugume et al. 2008). Myers et al. (2000) showed that leguminous plants in East Africa harbor common bean viruses, such as bean common mosaic necrosis virus (BCMNV). Moreover, using artificial inoculations, Njau and Lyimo (2000) have shown that common bean viruses are transmissible and cause symptoms in several leguminous plants.

Many viruses, including potyviruses, begomoviruses, and carlaviruses, are transmitted from one plant to another by vectors. For instance, begomoviruses are exclusively transmitted by whiteflies (Bemisia tabaci) (Rosen et al. 2015), whereas potyviruses are transmitted by aphids (Gadhave et al. 2019; Revers and Garcia 2015). Other viral vectors include grasshoppers, beetles, and plasmodiophorids (Kanyuka et al. 2003; Mello et al. 2010). All these vectors are 
abundant in Tanzania and may lead to the transmission of viruses between wild plants and crops, including common bean. There are other methods of virus transmission, including mechanical transmission (Rwegasira and Chrissie 2015). However, many of those methods are virus-specific; for example, begomoviruses are not known to be seed-transmitted (Inoue-Nagata et al. 2016).

Studies of the impact of vectors on virus transmission from wild plants to common bean require a thorough knowledge of the viruses present in wild plants, including an understanding of which wild plant hosts a particular virus and which insects prefer feeding on that wild plant. We have recently conducted several research studies to establish the incidence and distribution of common bean viruses in Tanzania and elsewhere (Mwaipopo et al. 2018). We have also characterized the means of virus dispersal by focusing on seedborne transmission (Nordenstedt et al. 2017). These studies indicated that common bean viruses are widespread in Tanzania and belong to at least 11 genera (Mwaipopo et al. 2018). The data also demonstrated that seed dispersal is not the main means by which pathogenic common bean viruses are spread in Tanzania (Nordenstedt et al. 2017). Therefore it is not clear how previously detected viruses persist in nature, what their alternative host plants are, and whether they serve as sources of infection for common bean.

This study aimed to determine whether alternate hosts have a central role in the epidemiology of common bean viral disease in Tanzania. To explore this possibility, we used a NGS technique, short interfering RNA (siRNA) sequencing, which can simultaneously detect multiple plant viruses (Kreuze et al. 2009), together with conventional RT-PCR to detect viruses in wild plants. The knowledge generated by this study should be useful for predicting crop viral disease outbreaks in different agricultural regions and for developing disease management strategies, including how to manage alternate hosts of crop viruses.

\section{Materials and Methods}

Collection of wild plant samples. Surveys to collect wild plant samples were conducted in four agricultural zones in Tanzania where common bean is grown (Mwaipopo et al. 2018). These surveys included 9 and 17 administrative regions and districts, respectively, in Eastern Tanzania, Northern Tanzania, and the southern highlands and the Lake zone of Tanzania (Supplementary Fig. S1). The map was drawn with ArcGis (version 10.4). A total of 1,430 wild plant leaf samples were collected within and up to $10 \mathrm{~m}$ away from common bean fields. Ten samples of different wild plant species were randomly collected per bean field and its environments, and they were preserved separately using a plant press and desiccants (calcium chloride and silica gel) (Vetten and Allen 1991).

RNA extraction. Total RNA was extracted from all 1,430 desiccated leaf samples using a modified cetyltrimethylammonium bromide (CTAB) method (Mwaipopo et al. 2018). The integrity of RNA was assessed visually by agarose gel electrophoresis. The RNA concentration and purity were determined by spectrophotometry using a Nanodrop 2000c UV-Vis Spectrophotometer (Thermo Scientific, Wilmington, DE).

NGS. A total of 1,430 leaf samples were separately collected from the same number of wild plants from nine administrative regions in Tanzania where common bean is one of the major crops. RNA was extracted from all samples; however, because of costs, only 139 samples were analyzed by siRNA sequencing. The samples were selected for sequencing based on variations in visible plant symptoms (a few symptomless plant samples were also included) and to include and represent four agricultural zones in Tanzania. The samples were divided into seven pools, with two sample pools representing each zone except for the Lake zone, which was represented by a single sample pool (Table 1 and Supplementary Table S1). Each pooled sample consisted of 10 to 30 individual samples mixed using equal amount of RNA (700 ng RNA per individual sample). When available, it was ensured that RNA from both legume and nonlegume plants were included in each pooled sample. The samples were named JDH-1 and JDH-5 (eastern zone), JDH-2 and JDH-6 (northern zone), JDH-3 and JDH-4 (southern highlands zone), and HXH-16 (Lake zone).

Based on the observations that wild plants around common bean fields harbor many viruses, some of which are related to viruses known to infect common bean, we initiated a transmission experiment in screenhouses. Experiments were conducted at the Sokoine University of Agriculture, and wild plant samples for inoculum were collected from nearby places in Mvomero district (eastern zone). Sap from 25 wild plants belonging to 16 plant species (Supplementary Table S2) were inoculated on leaves of four different common bean varieties: Pesa, Mwaspenjele, Rozikoko, and Rosenda. These varieties are highly susceptible to common bean viruses (our unpublished data). Sample pool AIVN-1 contained samples extracted from five wild plants (three plants of Bolusafra bituminosa Kuntze and two plants of Ocimum basilicum L.) that caused symptoms in common bean plants. Sample AIVN-2 contained RNA from a common bean plant that developed severe symptoms after inoculation with sap from $O$. basilicum. AIVN-3 contained samples from the four common bean plants that developed mild viral disease symptoms after inoculation with wild plants (Table 1).

Pooled RNA samples were shipped on dry ice to Fasteris SA (Plan-les-Outes, Switzerland), where small RNAs were isolated and sequenced. Quality control of the RNA was also performed there: RNA was quantified using Qubit (Thermofisher), and the quality was checked with a Bioanalyzer Nano chip (Agilent). Then, small RNAs were isolated from acrylamide gels and cDNA libraries were prepared and sequenced with an Illumina Genome Analyzer (HiSeq 3000/4000 platform, Illumina Inc., San Diego, CA) as described (Nordenstedt et al. 2017) or with Illumina NextSeq platform for samples AIVN-1 to AIVN-3. The change in platforms occurred because of the sequencing platform was updated at Fasteris SA. Bases were inferred from light intensity signals (base calling pipeline) with HiSeq Control Software 3.376, RTA 2.7.6, and bcl2fastq2.17 v2.17.1.14. The pipeline estimated the read quality according to the percentage of bases with a base quality of 30 or more $(<1$ error in 1,000 bases). The bases that corresponded to the standard Illumina adapters were removed by using the Trimmomatic package version 0.32 as explained by Bolger et al. (2014). The raw siRNA reads obtained by Illumina were deposited to the European Nucleotide Archive (ENA) as project PRJEB38859.

cDNA synthesis and PCR. The first-strand cDNA synthesis was performed for 1,430 RNA samples using Moloney Murine Leukaemia Virus Reverse transcription (M-MuLV RT; New England Biolabs (NEB), Ipswich, MA) following manufacturer's instructions with some modifications. The first mixture contained $1 \mu \mathrm{g}$ of RNA, $1 \mu \mathrm{l}$ of $100 \mu \mathrm{M}$ oligo(dT) $)_{18-21}$ or random hexamers (Bioneer, Seoul, South Korea), $1 \mu \mathrm{l}$ of dNTPs, and DEPC water to a final volume of $10 \mu$ l. The mixture was heated to $65^{\circ} \mathrm{C}$ for $5 \mathrm{~min}$ and spun down after chilling on ice for $2 \mathrm{~min}$. The second master mixture was prepared according to the standard protocol of the NEB using a final volume of $20 \mu \mathrm{l}$. Reactions primed with random hexamers and

Table 1. Wild plant and common bean samples analyzed by nextgeneration sequencing in 2017 and 2018

\begin{tabular}{lcclc}
\hline $\begin{array}{l}\text { Sample } \\
\text { pool }^{\mathbf{a}}\end{array}$ & Location $^{\mathbf{b}}$ & $\begin{array}{c}\text { Individual } \\
\text { samples }\end{array}$ & Type of sample & $\begin{array}{c}\text { Year of } \\
\text { collection }\end{array}$ \\
\hline JDH-1 & EZ & 20 & Wild plants & 2016 \\
JDH-2 & NZ & 16 & Wild plants & 2016 \\
JDH-3 & SHZ & 10 & Wild plants & 2016 \\
JDH-4 & SHZ & 19 & Wild plants & 2016 \\
JDH-5 & EZ & 20 & Wild plants & 2016 \\
JDH-6 & NZ & 24 & Wild plants & 2016 \\
HXH-16 & LZ & 30 & Wild plants & 2016 \\
AIVN-1 & EZ & 5 & Wild plants & 2018 \\
AIVN-2 & EZ & 1 & Common bean & 2018 \\
AIVN-3 & EZ & 4 & Common bean & 2018 \\
\hline
\end{tabular}

${ }^{a}$ JDH-1 to JDH-6, HXH-16, and AIVN-1 to AIVN-3 are sample code names given by the sequencing company.

b EZ, eastern zone; NZ, northern zone; SHZ, southern highlands zone; LZ, Lake zone in Tanzania. 
oligo(dT) $)_{18-21}$ were incubated at $37^{\circ} \mathrm{C}$ and $42^{\circ} \mathrm{C}$, respectively, for 90 min, and enzymes were inactivated at $65^{\circ} \mathrm{C}$ for $20 \mathrm{~min}$.

PCR was performed to confirm the presence of some viruses detected by NGS in wild plants. Because of costs, PCR was performed only to detect a few viruses: bean common mosaic virus (BCMV), BCMNV, cowpea mild mottle virus (CPMMV), cowpea chlorotic mottle virus (CCMV), cucumber mosaic virus (CMV), southern bean mosaic virus (SBMV), yam bean mosaic virus (YBMV), and peanut mottle virus (PeMoV). The primers used were designed using sequence information obtained through NGS during this study and published in the National Center for Biotechnology Information (NCBI) database (Supplementary Table S3). For BCMV, BCMNV, CPMMV, SBMV, YBMV, and PeMoV detection, AccuPower PCR PreMix (Bioneer, Seoul, South Korea) was used. The premix reaction contained $1 \mathrm{U}$ TopDNA polymerase, 250 $\mu \mathrm{M}$ dNTPs, $10 \mathrm{mM}$ Tris- $\mathrm{HCl}(\mathrm{pH} 9.0), 30 \mathrm{mM} \mathrm{KCl}, 1.5 \mathrm{mM}$ $\mathrm{MgCl}_{2}$, stabilizer, and a tracking dye; $1 \mu \mathrm{l}$ each of $10 \mu \mathrm{M}$ forward and reverse primer, $3 \mu \mathrm{l}$ of template cDNA, and nuclease-free water were added, with a final volume of $20 \mu \mathrm{l}$. For CMV and CCMV detection, OneTaq DNA polymerase was used. In this case, $0.5 \mu \mathrm{l}$ of $10 \mathrm{mM}$ dNTPs, $0.5 \mu \mathrm{l}$ of $10 \mu \mathrm{M}$ forward and reverse primers, $5 \mu \mathrm{l}$ of $5 \times$ OneTaq standard reaction buffer, $0.125 \mu \mathrm{l}$ OneTaq DNA polymerase, $5 \mu \mathrm{l}$ of DNA template, and nuclease-free water up to $25 \mu \mathrm{l}$ were added. PCR reactions were performed in a thermal cycler (Applied Biosystems) or in a TC-412 TECHNE PCR machine (Techne Inc., Burlington, NJ).

The PCR conditions for BCMV and BCMNV detection have been described previously (Mwaipopo et al. 2018). For other viruses, the following conditions were used: CPMMV, 1 cycle of $3 \mathrm{~min}$ at $94^{\circ} \mathrm{C}$ (initial denaturation), 35 cycles at $94^{\circ} \mathrm{C}$ for $45 \mathrm{~s}$ (denaturation), $56^{\circ} \mathrm{C}$ for $45 \mathrm{~s}$ (annealing), and $72^{\circ} \mathrm{C}$ for $1 \mathrm{~min}$ (extension), and a final extension at $72^{\circ} \mathrm{C}$ for $10 \mathrm{~min}$; CMV and CCMV, 1 cycle for $30 \mathrm{~s}$ at $94^{\circ} \mathrm{C}$ (initial denaturation), 35 cycles at $94^{\circ} \mathrm{C}$ for $30 \mathrm{~s}$ (denaturation), $50^{\circ} \mathrm{C}$ for $30 \mathrm{~s}$ (annealing), and $68^{\circ} \mathrm{C}$ for $45 \mathrm{~s}$ (extension), and a final extension at $68^{\circ} \mathrm{C}$ for $10 \mathrm{~min}$; $\mathrm{PeMoV}$, initial denaturation for $3 \mathrm{~min}$ at $94^{\circ} \mathrm{C}, 35$ cycles at $94^{\circ} \mathrm{C}$ for $45 \mathrm{~s}$ (denaturation), $53^{\circ} \mathrm{C}$ for $45 \mathrm{~s}$ (annealing), and $72^{\circ} \mathrm{C}$ for $1 \mathrm{~min}$ (extension), and a final extension at $72^{\circ} \mathrm{C}$ for $10 \mathrm{~min}$; and YBMV and SBMV, initial denaturation for $3 \mathrm{~min}$ at $94^{\circ} \mathrm{C}, 35$ cycles at $94^{\circ} \mathrm{C}$ for $25 \mathrm{~s}$ (denaturation), $50^{\circ} \mathrm{C}$ for $25 \mathrm{~s}$ (annealing), and $72^{\circ} \mathrm{C}$ for $30 \mathrm{~s}$ (extension), and a final extension at $72^{\circ} \mathrm{C}$ for $10 \mathrm{~min}$. PCR products were run in $1 \%$ agarose gels and stained with ethidium bromide. Gel images were captured under ultraviolet (UV) light using a Benchtop UV transilluminator (UVP; Upland, CA).

Mechanical transmission of viruses from wild to common bean plants. Transmission experiments were conducted in the screenhouse at Sokoine University of Agriculture in Morogoro. During the first experiment, two attempts were made to transmit YBMV from wild plants (Senna hirsuta [L.] Irwin \& Barneby)—collected from Morogoro Region (Mvomero district) in the eastern zone- to $11 \mathrm{com}$ mon bean varieties, namely Pesa, Zawadi, Mshindi, SUA 90, Rojo, Lymungo 90, Calima uyole, PASI, Rosenda, JESCA, and Uyole 96. The varieties were provided by bean breeders at Sokoine University of Agriculture and Tanzania Agricultural Research Institute. Seeds of each variety were sown in pots containing heat-sterilized soil and kept in the screenhouse. Based on our previous study (Nordenstedt et al. 2017), they contained no seedborne viruses. The inoculated plants of S. hirsuta showed mosaic symptoms and were confirmed by PCR to be infected with YBMV.

During the second experiment, attempts were made to transmit unknown viruses from 25 symptomatic legume and nonlegume wild plants-collected from Mvomero and Morogoro Rural districts in eastern Tanzania (Supplementary Table S2) - to four common bean varieties that are known to be susceptible to several common bean viruses. The bean varieties used here were Pesa, Mwaspenjele, Rozikoko, and Rosenda, which are known to be susceptible to BCMV, BCMNV, CPMMV, and SBMV (D. Mbanzibwa, B. Mwaipopo, and D. Chilagane, unpublished data). Four plants for each variety were inoculated at the trifoliate stage (approximately 8 days after sowing), and plants were watered three times per week. The leaf samples from symptomatic wild plants were collected in a cool box and used within $24 \mathrm{~h}$ for inoculation of common beans. The leaf samples were ground separately and carefully in $0.01 \mathrm{M}$ phosphate buffer $(\mathrm{pH}$ 7.0) using a ratio of 1:10 (weight/vol) and a mortar and pestle to generate plant sap. A pinch of 600 mesh carborundum was dusted on the leaves, and the sap from wild plants was gently rubbed on one of the three fully opened leaves on each common bean plant. After $30 \mathrm{~min}$, the plants were washed well using sterile water to remove the buffers and carborundum, and the plants were allowed to grow for 48 days or until they had all flowered.

DNA barcoding of wild plant species. DNA barcoding was performed to determine the identity (i.e., species) of the wild plants that were used for sap inoculations. The gene encoding maturase $\mathrm{K}$ $(m a t K)$ of the chloroplast was amplified with primer pair matk-F $\left(5^{\prime}\right.$ CGTACAGTACTTTTGTGTTTACGAG- $\left.3^{\prime}\right)$ /matk-R (5'-ACCCAG TCCATCTGGAAATCTTGGTTC-3') or matk2.1af (5'-ACTCAT CTGGAAATCTTAGT-3')/matk5r (5'-GTTCTAGCACAAGAAAG TCG- $\left.{ }^{\prime}\right)$. The $\operatorname{mat} K$ gene is one of the most variable genes in angiosperms and is a promising candidate for barcoding because of its high evolutionary rate, which is important for distinguishing plant species (Kar et al. 2015). AccuPower PCR PreMix was used for PCR amplification using $50 \mathrm{ng}$ of DNA template. The PCR conditions consisted of an initial denaturation $\left(94^{\circ} \mathrm{C}\right.$ for $\left.3 \mathrm{~min}\right)$ followed by 35 cycles at $94^{\circ} \mathrm{C}$ for $30 \mathrm{~s}$ (denaturation), $47^{\circ} \mathrm{C}$ for $30 \mathrm{~s}$ (annealing), and $72^{\circ} \mathrm{C}$ for $45 \mathrm{~min}$ (extension), and a final cycle (final extension) at $72^{\circ} \mathrm{C}$ for $10 \mathrm{~min}$. The PCR products were run in a $1 \%$ agarose gel containing ethidium bromide, and the amplicons were visualized with a Benchtop UV transilluminator. The samples were purified with a PCR purification kit (Bioneer), and both strands were Sanger-sequenced by Bioneer (South Korea) or by the sequencing facility at Mbeya Zonal Referral Hospital Laboratory (Tanzania).

Analysis of NGS and Sanger sequences. The NGS data were analyzed using the VirusDetect program version 1.6 and version 1.7 (Zheng et al. 2017). The reads of 21 to 24 nucleotides were selected, combined, and subsequently used for reference-guided and de novo assembly with comparisons with the plant virus reference database (VirusDetect virus_database 229) for virus identification. Default settings with a minimum read depth of five were used. The contigs obtained were checked for open reading frames using the ExPASy Translate tool (https://www.expasy.org/). The Sanger sequences of different virus isolates and chloroplast matK genes were blasted to the NCBI to obtain highly similar sequences for the purpose of virus and plant identification.

\section{Results}

Viruses detected in wild plants by siRNA sequencing. The sequencing resulted in a total of 36.9 to 102.5 million reads (read length, 1-50 nt) per pool (Table 2). In all sample pools except JDH$3(37.8 \%)$, the proportion of reads was highest for the insert range of 18 to $26 \mathrm{nt}(56.2-72.3 \%)$. The detected siRNAs (21-24 nt) ranged from 11.9 million reads (JDH-3; 23.6\%) to 34.6 million reads (JDH$2 ; 45.0 \%$ ) (Table 2). In some samples, a substantial number of these siRNAs aligned to the plant virus reference sequence database: $36.2 \%$ in sample pool JDH-1 (eastern zone) and $20.0 \%$ in sample pool HXH-16 (Lake zone). In the other samples, the percentage ranged from 1.2 to $3.2 \%$ (Table 2).

Several viruses belonging to different genera were detected in wild plant sample pools with VirusDetect (Table 3 and Supplementary Table S4). The highest number of different viruses was identified among samples collected from the eastern zone (16 identified viruses and unknown viruses from 7 genera; sample pools JDH-1 and JDH-5), followed by the northern zone (10 identified viruses and unknown viruses from 10 genera; sample pools JDH-2 and JDH-6) (Table 3 and Supplementary Table 4). Only tomato mosaic virus and unknown viruses from genus Begomovirus and Potyvirus were identified in samples from the Lake zone (sample pool HXH-16), and no virus (except an insect virus) was identified in samples collected from the southern highlands zone (sample pools JDH-3 and JDH-4) (Table 3 and Supplementary Table 4). The largest number of all detected viruses belonged to the genus Begomovirus. The second and third largest groups of detected viruses were potyviruses and carlaviruses, respectively (Table 3). 
Potyviruses SPFMV, sweet potato virus C (SPVC), and YBMV and carlaviruses CPMMV and potato virus S (PVS) were identified with high confidence in the eastern zone sample pools of wild plants (Table 3). The siRNA coverage of these viruses ranged from 63.9 to $99.6 \%$ compared with full-length viral sequences with an average identity of 90.1 to $97.3 \%$ (Table 3). CPMMV and YBMV were identified in sample pools of wild plants collected from both the eastern and northern zones. Furthermore, PeMoV (genus Potyvirus), CMV (genus Cucumovirus), and bean yellow disorder virus (BnYDV; Crinivirus) were highly represented by siRNA data in sample pools of plants from the northern zone (Table 3). The largest virus group among wild plants from both the eastern and northern zones, however, was the begomovirus group. Tomato leaf curl Uganda virus (ToLCUV) was most highly represented (coverage range, 39.1-86.8\%; average identity, 96.4-97.1\%). In addition, tomato leaf curl Toliara virus (ToLCToV, begomovirus), tomato leaf curl Arusha virus (ToLCArV), african cassava mosaic Burkina Faso virus (ACMBFV), tomato curly stunt virus (ToSCV), tomato yellow leaf curl Sardinia virus (TYLCSaV), tomato yellow leaf curl virus (TYLCV), hollyhock leaf crumple virus $(\mathrm{HoLCuV})$, cotton leaf curl

Table 2. Number of small RNA reads and reads that aligned to the plant virus reference database in wild plant sample pools

\begin{tabular}{|c|c|c|c|c|c|c|c|}
\hline \multirow[b]{2}{*}{ Sample pool } & \multirow[b]{2}{*}{ Location $^{\mathbf{a}}$} & \multirow[b]{2}{*}{ Total number of reads } & \multicolumn{2}{|c|}{$21-24 \mathrm{nt}$} & \multicolumn{3}{|c|}{ Aligned to virus reference database ${ }^{b}$} \\
\hline & & & Number of reads & Total (\%) & Number of reads & $\%(21-24 \mathrm{nt})$ & Number of contigs \\
\hline JDH-1 & $\mathrm{EZ}$ & $36,889,993$ & $14,958,750$ & 40.5 & 541,474 & 36.2 & 306 \\
\hline JDH-2 & $\mathrm{NZ}$ & $76,966,370$ & $34,611,953$ & 45.0 & 957,191 & 2.8 & 180 \\
\hline JDH-3 & SHZ & $50,365,426$ & $11,888,644$ & 23.6 & 154,917 & 1.3 & 5 \\
\hline JDH-4 & SHZ & $57,492,613$ & $16,225,049$ & 28.2 & 195,736 & 1.2 & 74 \\
\hline JDH-5 & EZ & $62,980,557$ & $25,423,783$ & 40.4 & 685,446 & 2.7 & 244 \\
\hline JDH-6 & $\mathrm{NZ}$ & $102,463,508$ & $33,258,639$ & 32.5 & $1,067,985$ & 3.2 & 145 \\
\hline НXH-16 & $\mathrm{LZ}$ & $58,082,228$ & $18,586,160$ & 32.0 & 371,005 & 20.0 & 61 \\
\hline
\end{tabular}

${ }^{a}$ EZ, eastern zone; NZ, northern zone; SHZ, southern highlands zone; LZ, Lake zone in Tanzania.

${ }^{\mathrm{b}}$ Reads (21-24 nt) that aligned to the plant virus reference sequence database (January 2020).

Table 3. Viruses detected in wild plants in Tanzania by siRNA sequencing (based on a BLASTN search of VirusDetect)

\begin{tabular}{|c|c|c|c|c|c|c|c|c|}
\hline Location $^{a}$ & $\begin{array}{c}\text { Sample } \\
\text { pool }\end{array}$ & Genus & $\begin{array}{l}\text { Accession } \\
\text { number }^{b}\end{array}$ & Virus & Sequence (length) & $\begin{array}{c}\text { Coverage } \\
(\%)^{\mathrm{c}}\end{array}$ & $\begin{array}{c}\text { Average } \\
\text { depth }^{d}\end{array}$ & $\begin{array}{c}\text { Average } \\
\text { identity } \\
(\%)^{\mathrm{e}}\end{array}$ \\
\hline \multirow[t]{20}{*}{ EZ } & \multirow[t]{6}{*}{ JDH-1 } & Begomovirus & AM701768 & Tomato leaf curl Toliara virus & DNA $(2,764 \mathrm{nt})$ & 52.3 & 85.8 & 96.2 \\
\hline & & Carlavirus & KC774020 & Cowpea mild mottle virus & RNA $(8,209 \mathrm{nt})$ & 47.1 & 8.4 & 97.4 \\
\hline & & Potyvirus & JN190431 & Yam bean mosaic virus & RNA $(9,649$ nt) & 78 & 346.1 & 90.1 \\
\hline & & Potyvirus & FJ155666 & Sweet potato feathery mottle virus & RNA $(11,004$ nt) & 67.7 & 75.9 & 94.7 \\
\hline & & Potyvirus & MF997470 & African eggplant mosaic virus & RNA $(9,694$ nt) & 50.4 & 864.3 & 83.8 \\
\hline & & Potyvirus & KP115621 & Sweet potato virus $\mathrm{C}$ & RNA $(10,830 \mathrm{nt})$ & 99.6 & 301.7 & 93.8 \\
\hline & \multirow[t]{14}{*}{ JDH-5 } & Begomovirus & EF194760 & Tomato leaf curl Arusha virus & DNA-A $(2,762 \mathrm{nt})$ & 34.9 & 235.5 & 93.7 \\
\hline & & Begomovirus & HE616777 & African cassava mosaic Burkina Faso virus & DNA-A $(2,770 \mathrm{nt})$ & 25.2 & 300.5 & 90.0 \\
\hline & & Begomovirus & AM701768 & Tomato leaf curl Toliara virus & DNA $(2,764 \mathrm{nt})$ & 24.6 & 309.1 & 94.8 \\
\hline & & Begomovirus & AF261885 & Tomato curly stunt virus & DNA-A $(2,766 \mathrm{nt})$ & 21.1 & 303.8 & 91.3 \\
\hline & & Begomovirus & KJ016240 & Emilia yellow vein virus & DNA-A $(2,726 \mathrm{nt})$ & 21.2 & 197.8 & 89.6 \\
\hline & & Begomovirus & KC953604 & Tomato yellow leaf curl Sardinia virus & DNA $(2,775 \mathrm{nt})$ & 20.6 & 212.1 & 90.5 \\
\hline & & Begomovirus & AJ132711 & Tomato yellow leaf curl virus & DNA $(2,771 \mathrm{nt})$ & 20.6 & 142.9 & 91.3 \\
\hline & & Begomovirus & DQ127170 & Tomato leaf curl Uganda virus & DNA-A $(2,747 \mathrm{nt})$ & 71.5 & 191.4 & 96.4 \\
\hline & & Carlavirus & KC774020 & Cowpea mild mottle virus & RNA $(8,209 \mathrm{nt})$ & 89.2 & 24.5 & 97.3 \\
\hline & & Carlavirus & FJ813512 & Potato virus $\mathrm{S}$ & RNA $(8,485 \mathrm{nt})$ & 63.9 & 8.0 & 96.5 \\
\hline & & Comovirus & X00206 & Cowpea mosaic virus & RNA1 $(5,889 \mathrm{nt})$ & 52.4 & 197.4 & 85.3 \\
\hline & & Comovirus & X00729 & Cowpea mosaic virus & RNA2 (3,481 nt) & 57.7 & 329.8 & 85.0 \\
\hline & & Potyvirus & JN190431 & Yam bean mosaic virus & RNA $(9,649 \mathrm{nt})$ & 83.9 & 618.4 & 89.8 \\
\hline & & Potyvirus & AF348210 & Cowpea aphid-borne mosaic virus & RNA $(9,465 \mathrm{nt})$ & 66.3 & 601.2 & 84.9 \\
\hline \multirow[t]{14}{*}{$\mathrm{NZ}$} & \multirow[t]{5}{*}{ JDH-2 } & Begomovirus & DQ127170 & Tomato leaf curl Uganda virus & DNA-A $(2,747 \mathrm{nt})$ & 39.1 & 58.7 & 96.9 \\
\hline & & Carlavirus & KJ534277 & Cowpea mild mottle virus & RNA $(1,238 n t)^{\mathrm{f}}$ & 70.8 & 9.5 & 98.4 \\
\hline & & Crinivirus & EU191905 & Bean yellow disorder virus & RNA-2 $(8,530 \mathrm{nt})$ & 54.3 & 20.4 & 96.5 \\
\hline & & Potyvirus & KU708532 & Peanut mottle virus & RNA $(9,734 \mathrm{nt})$ & 96.5 & 274.9 & 95.8 \\
\hline & & Potyvirus & JN190431 & Yam bean mosaic virus & RNA $(9,649 \mathrm{nt})$ & 83.7 & 943.7 & 89.1 \\
\hline & \multirow[t]{9}{*}{ JDH-6 } & Begomovirus & AJ542539 & Hollyhock leaf crumple virus & DNA $(2,740 \mathrm{nt})$ & 29.7 & 70.4 & 92.3 \\
\hline & & Begomovirus & DQ519575 & Tomato leaf curl Arusha virus & DNA-A $(2,766 \mathrm{nt})$ & 20.0 & 125 & 95.7 \\
\hline & & Begomovirus & DQ127170 & Tomato leaf curl Uganda virus & DNA-A $(2,747 \mathrm{nt})$ & 86.8 & 140.4 & 97.1 \\
\hline & & Begomovirus & AM701757 & Cotton leaf curl Gezira virus & DNA $(2,754 \mathrm{nt})$ & 57.0 & 101.9 & 97.0 \\
\hline & & Carlavirus & KJ534277 & Cowpea mild mottle virus & RNA $(1,238 n t)^{\mathrm{f}}$ & 58.6 & 16.0 & 98.1 \\
\hline & & Cucumovirus & KC527808 & Cucumber mosaic virus & RNA1 $(3,363 \mathrm{nt})$ & 98.7 & 103.4 & 96.6 \\
\hline & & Cucumovirus & KX660757 & Cucumber mosaic virus & RNA2 $(3,046 \mathrm{nt})$ & 93.3 & 38.0 & 97.1 \\
\hline & & Cucumovirus & KC527774 & Cucumber mosaic virus & RNA3 (2,220 nt) & 94.2 & 111.7 & 97.5 \\
\hline & & Polerovirus & KY364847 & Cowpea polerovirus 2 & RNA $(5,945 \mathrm{nt})$ & 26.8 & 7.4 & 99.1 \\
\hline \multirow[t]{2}{*}{$\mathrm{SHZ}$} & JDH-3 & & no detection & & & & & \\
\hline & JDH-4 & Cripavirus & MF458892 & Aphid lethal paralysis virus & $\begin{array}{l}\text { RNA ( } 9,828 \mathrm{nt}) \\
\text { insect virus }\end{array}$ & 71.8 & 50.2 & 97.0 \\
\hline LZ & HXH-16 & Tobamovirus & AB083196 & Tomato mosaic virus & RNA $(6,385 \mathrm{nt})$ & 90.5 & 18.2 & 99.2 \\
\hline
\end{tabular}

${ }^{a}$ EZ, eastern zone; NZ, northern zone; SHZ, southern highlands zone; LZ, Lake zone in Tanzania.

${ }^{\mathrm{b}}$ NCBI database: https://www.ncbi.nlm.nih.gov/.

${ }^{c}$ Percentage of the full-length reference virus sequence covered by contigs. Only viruses with sequence coverage $\geq 20.0 \%$ are shown.

${ }^{\mathrm{d}}$ Average number of times that each reference base was covered by reads.

e Average percentage of sequence identity of all contigs that aligned to the reference virus sequence.

${ }^{\mathrm{f}}$ Not a full-length virus sequence. However, included here because of high sequence identity and coverage. 
Gezira virus $(\mathrm{CLCuGeV})$, and emilia yellow vein virus (EYVV) were identified among reads with $20 \%$ or more coverage relative to the full-length viral sequence (Table 3). Furthermore, cowpea polerovirus 2 (CPPV2; unclassified Polerovirus) and viruses related to african eggplant mosaic virus (AEMV; Potyvirus), cowpea aphid-borne mosaic virus (CABMV; Potyvirus), and cowpea mosaic virus (CPMV; Comovirus) were detected.

Very few viruses were identified in the sample pools collected from the southern highlands and Lake zones (Table 3). Tomato mosaic virus (ToMV; Tobamovirus) was highly represented in the sample pool of wild plants from the Lake zone, but no plant virus that was previously known was identified in samples from the southern highlands zone.

In addition to the aforementioned viruses, all sample pools except for those from the southern highlands zone potentially also contained several previously unknown viruses. Several hits corresponding to different viruses in the genera Badnavirus, Begomovirus, Carlavirus, Crinivirus, Gammacarmovirus, Emaravirus, Polerovirus, Potyvirus, Roymovirus, Sobemovirus, Torradovirus, and Umbravirus were detected with BLASTN and/or BLASTX searches in different sample pools (Supplementary Table S4). However, their sequence identities with respect to reference viruses were low and their sequence coverage with respect to the full-length reference virus sequences was $<20 \%$ or was represented by partial virus sequences only (Supplementary Table S4). Therefore, the data do not allow conclusions regarding the presence of these viruses. Instead, some of these hits may illustrate the presence of a new, previously uncharacterized virus in the aforementioned genera. The sequence hits to viruses in the family Caulimoviridae may also characterize plant transposable elements. These issues were not investigated further during this study.
RT-PCR detection of viruses in wild plants. Attempts were made to detect BCMV, BCMNV, PeMoV, CPMMV, and YBMV in all 1430 wild plants using the RT-PCR method. YBMV was detected in S. hirsuta and PeMoV was detected in S. occidentalis (L.) Link. No positive PCR results were obtained for BCMV, BCMNV, or CPMMV. The PCR product of PeMoV was sequenced on both strands (accession no. MK330847). At the nucleotide level, the amplified PeMoV sequence was $99 \%$ identical to a PeMoV isolate (accession no. KY350138) from groundnut (Arachis hypogaea L.) in Brazil.

Mechanical transmission of wild plant viruses to common bean plants. Transmission succeeded only from four wild plants that belonged to two species, namely, B. bituminosa and $O$. basilicum (Fig. 1). Common bean plants separately inoculated with sap from three different plants of $B$. bituminosa developed varying symptoms depending on the common bean variety, such as rugosity on leaves, mild mosaic symptoms, and vein yellowing (Fig. 2). Common bean plants of variety Pesa inoculated with sap from the wild plant $O$. basilicum (Fig. 1B) developed severe necrosis on different parts of the plant and showed mosaic symptoms, slight leaf rolling, and stunted growth; they eventually died after 14 days. Subsequent inoculation of additional Pesa plants and three other common bean varieties (Mwaspenjele, Rozikoko, and Rosenda) with the sap from the infected Pesa plants developed symptoms of similar severity, but the plants survived.

To determine whether the observed viral symptoms were caused by BCMNV or BCMV, the plants were tested by PCR; however, neither BCMNV nor BCMV was detected. The siRNA data analysis indicated that the wild plants (sample AIVN-1) contained several viruses. Full-length RNA1, RNA2, and RNA3 of CMV were highly covered with contigs (88.5-98.6\%) with an average identity of 91.5
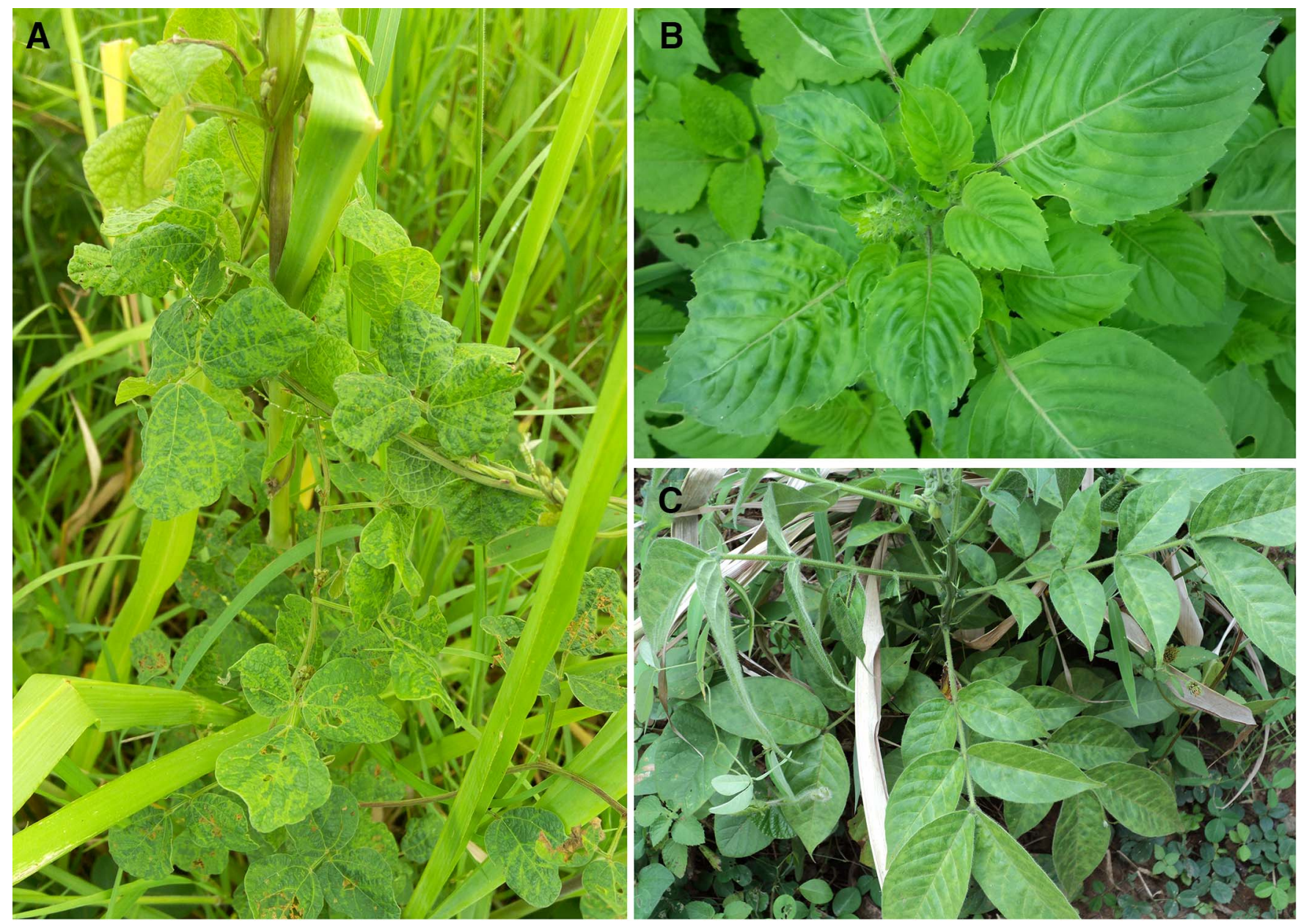

Fig. 1. Wild plants with viral disease symptoms. The plant species shown are the wild legume A, Bolusafra bituminosa, B, Ocimum basilicum, and C, Senna hirsuta. 
to $94.7 \%$ (Table 4). Therefore, the data suggested that CMV (genus Cucumovirus) was present in the samples (Table 4). In addition, a mitovirus (likely originating from a fungal contaminant) was identified with high probability. In addition to these viruses, a BLASTN search with VirusDetect against the plant virus reference database suggested the presence of viruses from three more genera (Begomovirus, Bromovirus, Deltapartitivirus) (Table 4). A subsequent
BLASTX search with the unidentified contigs resulted in hits for viruses from several genera (Alphaendornavirus, Begomovirus, Bromovirus, Polerovirus, Torradovirus), including those from family Caulimoviridae (Badnavirus Caulimovirus, Petuvirus, Soymovirus) (Supplementary Table S5). The average identity of reference viruses was relatively low (43-83\%) and did not allow conclusions regarding the detected viruses.
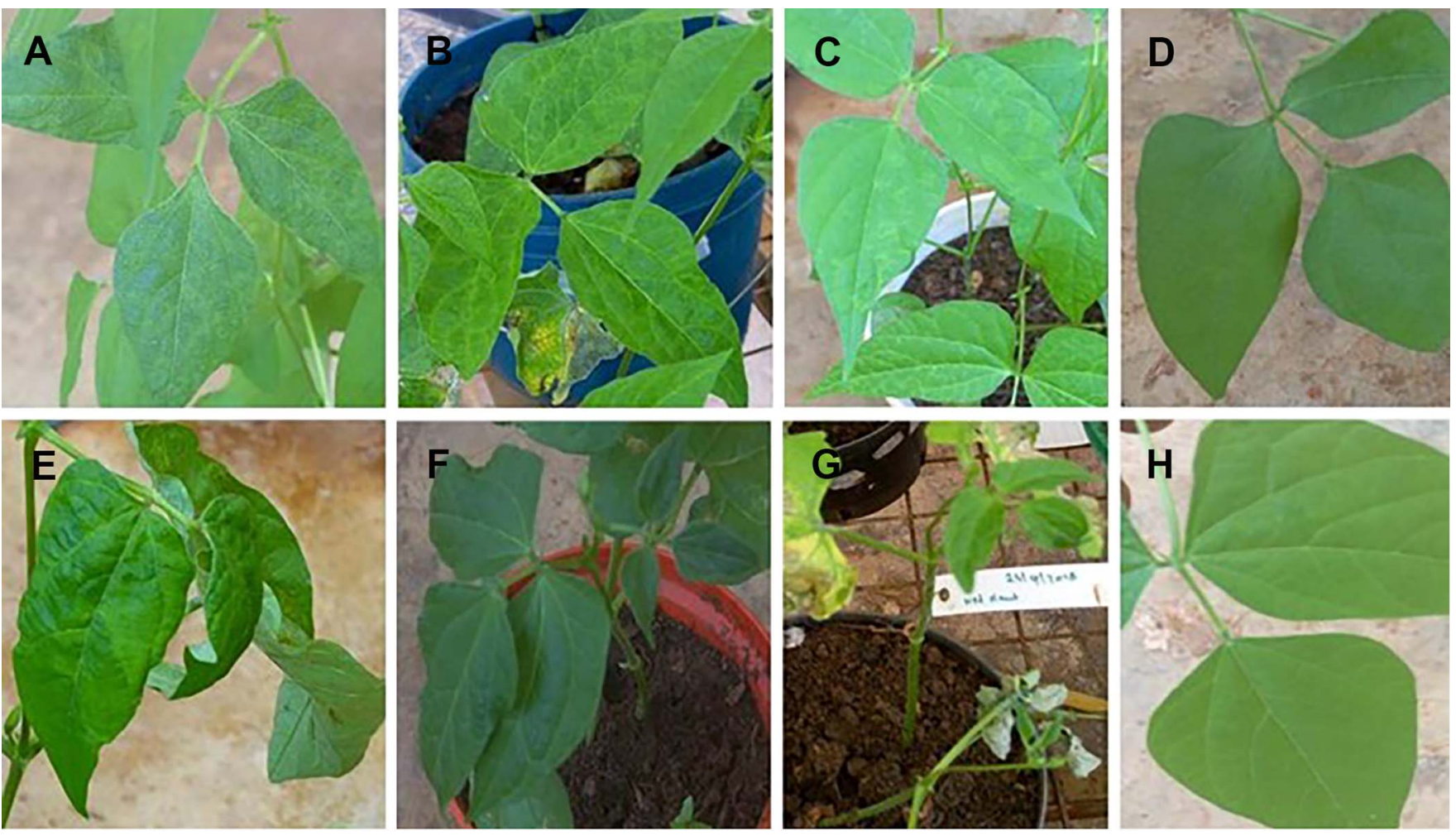

Fig. 2. Viral disease symptoms developed in common bean plants inoculated separately with sap from different wild plants. A to D, Plants with viral disease symptoms-rugosity on leaves, mild mosaic symptoms, and vein yellowing-after inoculation with sap from three different Bolusafra bituminosa plants. Common bean varieties shown are A, Mwaspenjele, B, Rosenda, C, Pesa, and D, Rozikoko. E to H, Viral disease symptoms-severe necrosis on different parts of the plant, mosaic symptoms, leaf rolling, and stunted growth-expressed in common bean plants after inoculation with sap from Ocimum basilicum. The genotypes inoculated with sap from O. basilicum are E, Mwaspenjele, F, Rosenda, G, Pesa, and H, Rozikoko.

Table 4. Viruses detected by siRNA sequencing in wild plants used as inoculum and in common bean plants after mechanical transmission

\begin{tabular}{|c|c|c|c|c|c|c|c|}
\hline Pool & Accession number ${ }^{a}$ & Virus $^{b}$ & Genus & Sequence (length) & Coverage $(\%)^{\mathrm{c}}$ & Average depth ${ }^{d}$ & Average identity $(\%)^{\mathrm{e}}$ \\
\hline \multirow[t]{7}{*}{ AIVN-1 } & JX993909 & CMV & Cucumovirus & RNA1 (3,385 nt) & 96.8 & 1,017 & 91.5 \\
\hline & KJ400003 & CMV & Cucumovirus & RNA2 (3,057 nt) & 88.5 & 666 & 92.8 \\
\hline & DQ006805 & CMV & Cucumovirus & RNA3 (2,414 nt) & 98.6 & 1,832 & 94.7 \\
\hline & LC089013 & PaLCuGdV & Begomovirus & DNA (2,732 nt) & 25.5 & 1,580 & 82.8 \\
\hline & HQ611268 & CCMV & Bromovirus & RNA3 (2,177 nt) & 11.0 & 4,547 & 82.8 \\
\hline & LN680393 & PiCV1 & Deltapartitivirus & $\operatorname{RdRp}(1,967 \mathrm{nt})$ & 16.7 & 2,526 & 94.3 \\
\hline & MF196914 & ObRV2 & Mitovirus & RNA $(2,784 \mathrm{nt})$ & 93.2 & 78 & 97.0 \\
\hline \multirow[t]{4}{*}{ AIVN-2 } & KT350980 & CMV & Cucumovirus & RNA1 (3,369 nt) & 98.3 & 4,507 & 92.8 \\
\hline & LC363918 & CMV & Cucumovirus & RNA2 (3,058 nt) & 93.9 & 4,297 & 91.3 \\
\hline & DQ006805 & CMV & Cucumovirus & RNA3 (2,414 nt) & 98.6 & 5,784 & 94.3 \\
\hline & LN680393 & PiCV1 & Deltapartitivirus & $\operatorname{RdRp}(1,967 \mathrm{nt})$ & 16.1 & 3,292 & 95.5 \\
\hline \multirow[t]{7}{*}{ AIVN-3 } & KT456287 & PvEV-1 & Alphaendornavirus & RNA (14,072 nt) & 99.0 & 157 & 98.6 \\
\hline & DQ875594 & SBMV & Sobemovirus & RNA (4,132 nt) & 99.1 & 5,406 & 98.5 \\
\hline & KT350980 & CMV & Cucumovirus & RNA1 (3,369 nt) & 12.0 & 7.6 & 99.0 \\
\hline & DQ412732 & CMV & Cucumovirus & RNA3 (2,220 nt) & 70.2 & 23.6 & 97.2 \\
\hline & AB 183263 & BMV & Bromovirus & RNA2 (2,867 nt) & 13.1 & 2,952 & 80.0 \\
\hline & HQ611268 & CCMV & Bromovirus & RNA3 (2,177 nt) & 11.3 & 5,571 & 82.9 \\
\hline & LN680393 & PiCV1 & Deltapartitivirus & $\operatorname{RdRp}(1,967 \mathrm{nt})$ & 17.7 & 2,827 & 97.4 \\
\hline
\end{tabular}

a NCBI database: https://www.ncbi.nlm.nih.gov/.

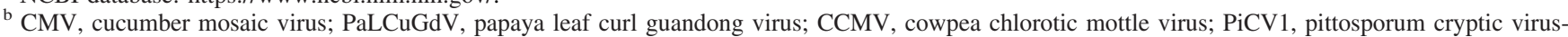
1; ObRV2, ocimum basilicum RNA virus 2; PvEV-1, phaseolus vulgaris endornavirus 1; SBMV, southern bean mosaic virus isolate; BMV, brome mosaic virus.

${ }^{c}$ Percentage of the full-length reference virus sequence covered by contigs.

d Average number of times each reference base was covered by reads.

e Average percentage of sequence identity of all contigs that aligned to the reference virus sequence. 
An analysis of the sample AIVN-2 from common bean plants that contained virus(es) mechanically transmitted from $O$. basilicum strongly suggested the presence of CMV (Table 4), which causes one of the most devastating diseases of common bean. RNA1, RNA2, and RNA3 of CMV were highly covered by contigs (98.3, 93.9, and $98.6 \%$, respectively) with a very high average depth $(>4,000)$. Transmission from wild plants was strongly supported with an extremely high identity of contigs of CMV in AIVN-1 and AIVN-2. In the sample pool AIVN-3, several viruses were detected (Table 4). Phaseolus vulgaris alphaendornavirus 1 and SBMV were highly represented with siRNA data, but they were not identified among the corresponding wild plant samples. Therefore, these viruses were not mechanically transmitted; instead, they were most likely transmitted via seed or via seed and soil contamination, respectively (Nordenstedt et al. 2017). In addition to PvEV-1 and SBMV, an unknown bromovirus related to CCMV and brome mosaic virus (BMV) and a cucumovirus related to CMV were identified (Table 4).

RT-PCR confirmation of transmitted viruses. The transmission of CMV and an unknown bromovirus from wild plants to common bean plants was confirmed by RT-PCR. The three common bean plants inoculated with sap from three different $B$. bituminosa plants were suspected to contain a bromovirus related to CCMV. PCR products of expected sizes were detected using CCMV-specific primers (Fig. 3A and B). Sequencing of the product indicated that the sequence was $77 \%$ identical to different isolates of CCMV. The sequence was almost identical (except for a single mismatch) to the CCMV contig generated from siRNA reads of wild plants. Therefore, the data confirmed the presence of a bromovirus related to CCMV in the common bean plants. We tentatively named the virus bolusafra mosaic virus (BoMV) because it was originally isolated from $B$. bituminosa plants and predominantly caused mosaic symptoms.

CMV was detected in a fourth common bean plant that was inoculated with sap from $O$. basilicum (Fig. 3C). Sequencing of the PCR product indicated that the sequence was $96 \%$ identical to the $\mathrm{CP}$ encoding region of CMV isolate PV-0506 from Solanum lycopersicum (accession no. KX525736). Neither CMV nor CCMV was detected in a fifth common bean plant inoculated with sap from $B$. bituminosa. This common bean plant was later shown to be infected with SBMV (data not shown), although $B$. bituminosa plants collected here were not infected with SBMV, as was confirmed by PCR. This suggests that this common bean plant was contaminated during handling in the screenhouse.
YBMV was not mechanically transmissible to common bean. The siRNA data analysis indicated that YBMV was one of the most common viruses in wild plants. The RT-PCR results showed that this virus was infecting $S$. hirsuta, a plant that is widely spread around common bean fields in the eastern zone (Fig. 1C and Fig. 4). Moreover, YBMV is known to infect common bean (Yarwood 1957) and is closely related to BCMV and BCMNV, two important viruses of common bean. Therefore, mechanical transmission from fresh leaf samples collected separately from three $S$. hirsuta plants that showed clear mosaic symptoms was attempted. The sap was used for inoculation of 11 common bean varieties, namely, Pesa, Zawadi, Mshindi, SUA 90, Rojo, Lymungo 90, Calima uyole, PASI, Rosenda, JESCA, and Uyole 96. Despite repeated attempts, no single common bean plant developed any kind of viral symptoms, and RT-PCR detection failed to detect the presence of the virus in the plants. These data suggest that the virus is not mechanically transmissible to common bean plants. Alternatively, $S$. hirsuta may contain a ribosome inhibitory protein or other viral inhibiting activity that hampered virus transmission to common bean plants.

\section{Discussion}

Among the major biotic factors constraining common bean production worldwide are diseases that are caused by different plant viruses (Segundo et al. 2008). A recent comprehensive survey of common bean viruses revealed that $>15$ viruses belonging to 11 genera infect common bean in Tanzania (Mwaipopo et al. 2018). Because seed transmission of these pathogenic viruses to $P$. vulgaris, an annual crop, is not common (Nordenstedt et al. 2017), it is likely that the viruses are surviving in alternative host plants from which they are transmitted to common bean plants when they are grown in proximity.

Detection of common bean viruses in wild plants has been reported for samples collected from Eastern Africa and other parts of the world (Sengooba et al. 1997; Spence and Walkey 1995; Tugume et al. 2008; Worrall et al. 2015). However, this study is the first comprehensive survey of viruses in wild plants in Tanzania focused on identifying wild plant species with the potential to harbor common bean viruses. Our work also represents the first time that the robust and sensitive technique NGS — specifically, siRNA sequencing-was used to detect viruses in wild plants collected from nearly all areas in which common bean is grown in Tanzania.

During this work, numerous plant viruses, representatives of potentially up to 25 different genera, were detected in wild plants

A

B

C

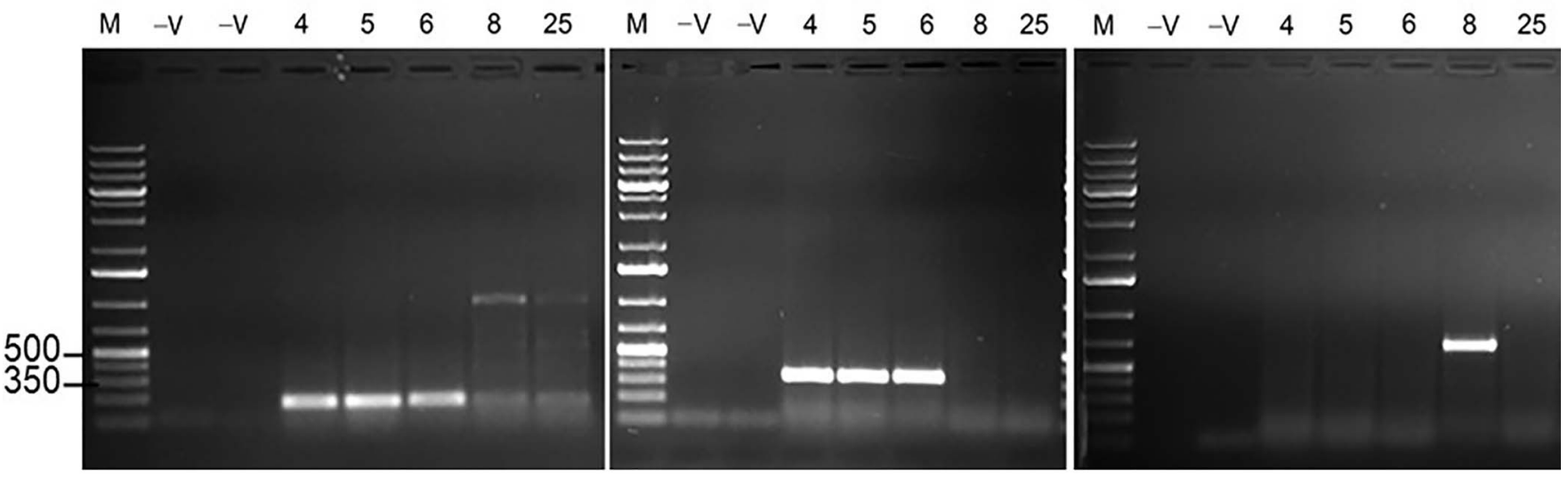

Fig. 3. Detection of cucumber mosaic virus (CMV) and a bromovirus related to cowpea chlorotic mottle virus (CCMV) in common bean plants inoculated with sap from Bolusafra bituminosa and Ocimum basilicum. Detection of a bromovirus related to CCMV in common bean plants using A, CCMV-specific primer pair CCMVF1/ CCMVR1, which amplifies a 170-nt fragment of CCMV coat protein (CP) in RNA3, and B, CCMV-specific primer pair CCMVF1/CCMVR2, which amplifies a 333-nt fragment of CCMV CP (Supplementary Table 3). Samples 4 to 6 (common bean plants inoculated with sap from B. bituminosa) were deemed virus-positive based on the presence of PCR products of the expected size, whereas no virus was detected in sample 8 (common bean inoculated with sap from 0 . basilicum) and sample 25 (common bean inoculated with sap from B. bituminosa). C, Detection of CMV using primer pair AH-CMVF1/AH-CMVR1, which amplifies a 650-nt fragment of the CMV CP-encoding region. Sample 8 (common bean inoculated with sap from $\mathrm{O}$. basilicum) was deemed virus-positive. M, DNA marker; $-\mathrm{V}$, a fresh common bean leaf with no CCMV or CMV infection (negative control). 
growing around common bean fields in four agricultural regions in Tanzania. Wild plant samples collected from the eastern and northern zones contained the highest number of different viruses, whereas among those from the Lake zone and, especially, the southern highlands zone, only a few viruses were detected. Among the detected viruses, CMV, PeMoV, YBMV, CABMV, CPMV, CPMMV, BnYDV, ToLCUV, ToLCArV, and TYLCV have been reported to infect common bean plants (Bashir et al. 2002; Bock and Kuhn 1975; Ji et al. 2012; Lamas et al. 2017; Martín et al. 2011; Mwaipopo et al. 2018; Patil and Kumar 2015).

Interestingly, most of the detected viruses belonged to the genera Begomovirus, Potyvirus, and Carlavirus. Most viruses that cause devastating crop diseases belong to the first two genera (Gibbs et al. 2008; Rey et al. 2012). However, carlaviruses are normally associated with latent infections, but they may induce synergistic infections with other viruses, such as those in the crinivirus group, to cause severe diseases (Untiveros et al. 2007). In East Africa, Tanzania in particular, viruses from these three genera have been detected in important food crops, such as cassava, sweet potato, and common bean (Aloyce et al. 2013; Mbanzibwa et al. 2014; Mwaipopo et al. 2018), where they can cause severe viral disease symptoms that translate to reduced yields. Similarly, viruses belonging to other genera, such as Cucumovirus (e.g., CMV) and Crinivirus (e.g., BnYDV), can cause severe diseases in common bean and other crops (Zitter and Murphy 2009). Therefore, our data revealed that wild plants harbor viruses related to those known to infect and cause diseases in crops; thus, they may serve as reservoirs for these viruses. We also found that the wild plants studied here contained potential new virus species from several different genera that are currently unknown and need further characterization.

Only one virus was detected in wild plant samples collected from the southern highlands of Tanzania. The short sequence of the detected virus was related to BCMV. These findings are consistent with those of previous studies that found common bean viruses to be rare in this region (Mwaipopo et al. 2018; Myers et al. 2000). Myers et al. (2000) attributed the low incidence of viruses in the southern highlands of Tanzania to low populations of vectors. The rare occurrence of viruses in wild plants in the southern highlands makes this area ideal for use in the production of seeds of different crops.

RT-PCR was conducted for 1,430 wild plant samples to detect common bean viruses YBMV, PeMoV, BCMV, BCMNV, and CPMMV. Although all five viruses were suggested to be present based on NGS, RT-PCR detected only YBMV and PeMoV in three samples and one sample, respectively. Both viruses were detected in
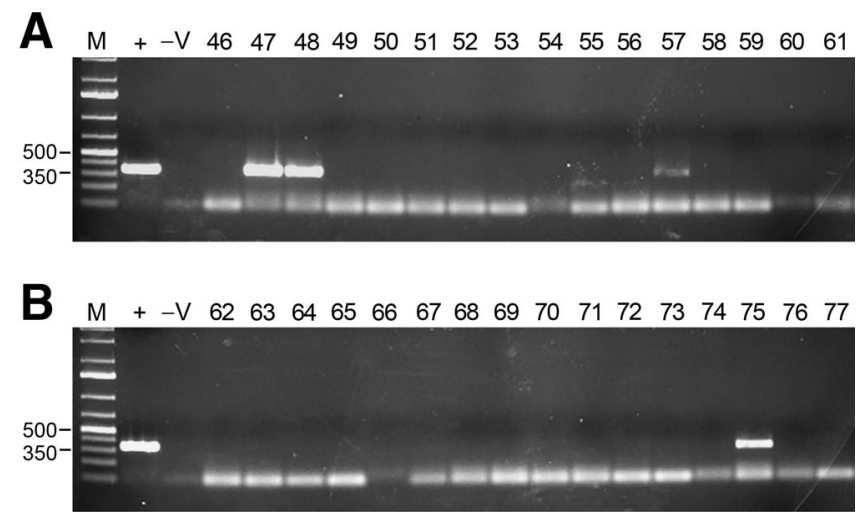

Fig. 4. RT-PCR detection of yam bean mosaic virus (YBMV) in wild plant samples that were suggested to contain this virus based on siRNA data analysis. The primer pair BC-YBMVF1/BC-YBMVR1, designed to amplify a region of the coat protein sequence, was expected to yield a PCR amplicon of $350 \mathrm{bp}$. A, Controls and samples 46 to 61 . B, Controls plus samples 62 to 77 . Samples 47 , 48,57 in A and sample 75 in B were deemed virus-positive based on the presence of an amplified fragment of the expected size. +, sample from a plant confirmed to contain YBMV; $-\mathrm{V}$, a fresh common bean leaf with no YBMV infection (negative control); M, DNA marker. The lowest band of the DNA marker is $75 \mathrm{bp}$, and the low bands around this size were likely primer dimers. legumes. We believe the failure to detect BCMV, BCMNV, and CPMMV could be speculatively explained by two reasons: the viruses were present at very low titers in these plants, a problem that was exacerbated by the use of RNA from dry leaf samples, or the viruses represented distinct strains of BCMV and BCMNV or closely related (but as yet undescribed) virus species for which the primers could not anneal. Previously, it was demonstrated that NGS could detect viruses in samples that were otherwise considered virusfree (Kreuze et al. 2009). This study and our previous analysis (Mwaipopo et al. 2018) provide further evidence of the higher sensitivity of NGS compared with RT-PCR, especially when dry leaf samples are used.

Mechanical transmission studies using inocula from 25 wild plants showed that only two viruses (CMV and a bromovirus related to CCMV and BMV) infected and caused symptoms in common bean plants. These viruses were transmitted from four plants belonging to only two species. It is worth noting that these four wild plants were infected with several viruses. In addition to four viruses that were highly represented in sample pools based on siRNA data, there were hits for several other potential viruses. The data indicated that only a few viruses could be transmitted from wild plants to common bean through mechanical transmission. It is possible that some of these viruses may require a different means of transmission to infect common bean. However, some of the viruses that were not mechanically transmitted in our study (e.g., YBMV) have been transmitted through the same means in addition to being transmitted using vectors (Damayanti et al. 2008).

The CMV detected during this work and that transmitted to common bean was most closely related to a CMV that was isolated from tomato in China. Although the sequences of the CMV in wild plants and common bean were only $99.3 \%$ identical, we are convinced that they represent the same isolate. The fact that CMV caused severe disease symptoms in common bean plants is worrying because this virus is widespread and has been detected by NGS in common bean in Tanzania (Mwaipopo et al. 2018) and Kenya (Mutuku et al. 2018). In Tanzania, CMV has also been detected in Vigna unguiculata, Cucumis sativus, Citrullus lanatus, Cucurbita pepo, Cucumis hystrix, and Luffa aegyptiaca (Sydänmetsä and Mbanzibwa 2016).

A new bromovirus, tentatively named bolusafra mosaic virus (BoMV), that is related to BMV and CCMV was detected in wild plants and was readily transmitted mechanically to and caused symptoms in plants of all common bean varieties tested. BMV and CCMV were not detected in common bean plants in comprehensive surveys of common bean viruses recently conducted in Tanzania (Mwaipopo et al. 2018). This could be because of inefficient vector transmissibility. For example, beetles transmit CCMV relatively inefficiently (Hobbs and Fulton 1978); therefore, they may not be a threat to common bean production in the country. CCMV does, however, infect common bean in the Americas (Fulton et al. 1975; Hobbs and Fulton 1978) and may occur in other areas where cowpea and common bean plants are grown.

YBMV was detected in $S$. hirsuta, a plant species that is widely distributed around common bean fields in Morogoro in the eastern zone. However, mechanical transmission of YBMV from $S$. hirsuta to different genotypes of common bean failed despite repeated attempts. No viral symptoms were detected in the inoculated plants, and no virus was detected by RT-PCR. It is possible that the common bean varieties used during this study are resistant to YBMV despite their being susceptible to many viruses. For example, an isolate from Indonesia initially reported as BCMV but with $96.6 \%$ nucleotide identity to the Peruvian isolate first named as YBMV has been shown to be mechanically and aphid transmissible (Damayanti et al. 2008) Therefore, future studies may need to use more common bean varieties and focus on vector transmission of YBMV from $S$. hirsuta to common bean.

During this study, there were very few viruses transmitted from wild plants to common bean using our methods; however, as noted, not all viruses are mechanically transmissible. It is also possible that some of the viruses found in wild plants infect cultivated crops other than $P$. vulgaris. For example, SPFMV was detected in wild plants in the eastern zone and is known to infect sweet potato (Sivparsad 
and Gubba 2013). These additional detected viruses could be a threat to other important crops in East Africa, including cassava (e.g., ACMBFV), okra (Okra yellow crinkle virus), tomato (tomato leaf curl virus), and groundnuts (groundnut rosette virus). Therefore, the information generated from this work may be useful for the management of virus diseases of other crops.

In conclusion, wild plants in different areas of Tanzania harbor many different viruses belonging to various genera, including the most important ones, Begomovirus, Potyvirus, and Carlavirus, known for their effects on several crops. Some of these viruses were shown to cause diseases in common bean plants. Wild plants also contained several unknown virus species that potentially can cause diseases in common bean and in other important crop plants. Although this work was focused on detecting viruses that could infect common bean, we note that the detected viruses have the potential to infect a wide range of important crops in the country. This is consistent with mixed cropping practices observed in Tanzania. The potential of some viruses to infect common bean when grown in proximity with infected wild plants was demonstrated through mechanical transmission of CMV and a bromovirus. Failure to detect viruses using RT-PCR highlights the importance of developing protocols and guidelines for the detection of viruses in wild plants. Future studies should investigate the possibility of transmitting these many viruses using vectors and should include attempts to transmit the viruses to different crops grown in surveyed areas.

\section{Acknowledgments}

We thank CSC-IT Center for Science, Finland, for computational resources. Supplementary Fig. 1 was kindly developed by Dr. Happyness G. Mollel. We thank all the individuals who participated in surveys (J. Mugini, E. Kweka, F. Swai, M. Kilango, M. William, and E. Kadege). We acknowledge the two anonymous reviewers whose comments helped us to improve the quality of this manuscript.

\section{Literature Cited}

Alicai, T., Ndunguru, J., Sseruwagi, P., Tairo, F., Okao-Okuja, G., Nanvubya, R., Kiiza, L., Kubatko, L., Kehoe, M. A., and Boykin, L. M. 2016. Cassava brown streak virus has a rapidly evolving genome: implications for virus speciation, variability, diagnosis and host resistance. Sci. Rep. 6:36164.

Aloyce, R. C., Tairo, F., Sseruwagi, P., Rey, M. E., and Ndunguru, J. 2013. A single-tube duplex and multiplex PCR for simultaneous detection of four cassava mosaic begomovirus species in cassava plants. J. Virol. Methods 189:148-156.

Amisse, J. J. G., Ndunguru, J., Tairo, F., Boykin, L. M., Kehoe, M. A., Cossa, N., Ateka, V., Rey, C., and Sseruwagi, P. 2019. First report of Cassava brown streak viruses on wild plant species in Mozambique. Physiol. Mol. Plant Pathol. 105:88-95.

Bashir, M., Ahmad, Z., and Ghafoor, A. 2002. Cowpea aphid-borne mosaic potyvirus: a review. Int. J. Pest Manage. 48:155-168.

Bock, K. R., and Kuhn, C. W. 1975. Peanut mottle virus. CMI/AAB Descriptions of Plant Viruses, No. 141. Association of Applied Biologists, Wellesbourne, UK.

Bolger, A. M., Lohse, M., and Usadel, B. 2014. Trimmomatic: a flexible trimmer for Illumina sequence data. Bioinformatics 30:2114-2120.

Damayanti, T. A., Susilo, D., Nurlaelah, S., Sartiami, D., Okuno, T., and Mise, K. 2008. First report of Bean common mosaic virus in yam bean [Pachyrhizus erosus (L.) Urban] in Indonesia. J. Gen. Plant Pathol. 74:438-442.

Fulton, J. P., Gámez, R., and Scott, H. A. 1975. Cowpea chlorotic mottle and Bean yellow stipple viruses. Phytopathology 65:741-742.

Gadhave, K. R., Dutta, B., Coolong, T., and Srinivasan, R. 2019. A nonpersistent aphid-transmitted Potyvirus differentially alters the vector and non-vector biology through host plant quality manipulation. Sci. Rep. 9:2503.

Gibbs, A. J., Ohshima, K., Phillips, M. J., and Gibbs, M. J. 2008. The prehistory of potyviruses: Their initial radiation was during the dawn of agriculture. PLoS One 3:e2523.

Hobbs, H. A., and Fulton, J. P. 1978. Bettle transmission of cowpea chlorotic mottle virus. Phytopathology 69:255-256.

Inoue-Nagata, A. K., Lima, M. F., and Gilbertson, R. L. 2016. A review of geminivirus (begomovirus) diseases in vegetables and other crops in Brazil: current status and approaches for management. Hortic. Bras. 34:8-18.

Ji, Y. H., Cai, Z. D., Zhou, X. W., Liu, Y. M., Xiong, R. Y., Zhao, T. M., Yu, W. G., Tao, X. R., and Zhou, Y. J. 2012. First report of Tomato yellow leaf curl virus infecting common bean in China. Plant Dis. 96:1229.

Kanyuka, K., Ward, E., and Adams, M. J. 2003. Polymyxa graminis and the cereal viruses it transmits: a research challenge. Mol. Plant Pathol. 4:393-406.
Kar, P., Goyal, A., and Sen, A. 2015. Maturase K gene in plant DNA barcoding and phylogenetics. Pages 79-90 in: Plant DNA Barcoding and Phylogenetics. M. A. Ali, G. Gabor, and F. Al-Hemaid, eds. Lambert Academic Publishing, Germany.

Kreuze, J. F., Perez, A., Untiveros, M., Quispe, D., Fuentes, S., Barker, I., and Simon, R. 2009. Complete viral genome sequence and discovery of novel viruses by deep sequencing of small RNAs: A generic method for diagnosis, discovery and sequencing of viruses. Virology 388:1-7.

Lacroix, C., Renner, K., Cole, E., Seabloom, E. W., Borer, E. T., and Malmstrom, C. M. 2016. Methodological guidelines for accurate detection of viruses in wild plant species. Appl. Environ. Microbiol. 82:1966-1975.

Lamas, N. S., Matos, V. O. R. L., Alves-Freitas, D. M. T., Melo, F. L., Costa, A. F., Faria, J. C., and Ribeiro, S. G. 2017. Occurrence of Cowpea mild mottle virus in common bean and associated weeds in Northeastern Brazil Plant Dis. 101:1828.

Martín, G., Cuadrado, I. M., and Janssen, D. 2011. Bean yellow disorder virus: parameters of transmission by Bemisia tabaci and host plant range. Insect Sci. 18:50-56.

Mbanzibwa, D. R., Tugume, A. K., Chiunga, E., Mark, D., and Tairo, F. D. 2014. Small RNA deep sequencing-based detection and further evidence of DNA viruses infecting sweet potato plants in Tanzania. Ann. Appl. Biol. 165:329-339.

Mello, A. F., Clark, A. J., and Perry, K. L. 2010. Capsid protein of cowpea chlorotic mottle virus is a determinant for vector transmission by a beetle. $\mathrm{J}$ Gen. Virol. 91:545-551.

Morales, F. J., and Castaño, M. 1987. Seed transmission characteristics of selected bean common mosaic virus strains in differential bean cultivars. Plant Dis. 71:51-53.

Mutuku, J. M., Wamonje, F. O., Mukeshimana, G., Njuguna, J., Wamalwa, M. Choi, S.-K., Tungadi, T., Djikeng, A., Kelly, K., Entfellner, J.-B. D., Ghimire, S. R., Mignouna, H. D., Carr, J. P., Jagger, J. W., and Harvey, J. J. W. 2018. Metagenomic analysis of plant virus occurrence in common bean (Phaseolus vulgaris) in Central Kenya. Front. Microbiol. 9:2939.

Mwaipopo, B., Nchimbi Msolla, S., Njau, P., Mark, D., and Mbanzibwa, D. R. 2018. Comprehensive surveys of Bean common mosaic virus and Bean common mosaic necrosis virus and molecular evidence for occurrence of other Phaseolus vulgaris viruses in Tanzania. Plant Dis. 102:2361-2370.

Myers, J. R., Mink, G. A., and Mabagala, R. 2000. Surveys for bean common mosaic virus in East Africa. Bean Improvement Cooperatives (BIC) 43:13-14.

Ndunguru, J., Legg, J. P., Aveling, T. A. S., Thompson, G., and Fauquet, C. M. 2005. Molecular biodiversity of cassava begomoviruses in Tanzania: evolution of cassava geminiviruses in Africa and evidence for East Africa being a center of diversity of cassava geminiviruses. Virol. J. 2:21.

Njau, P. J. R., and Lyimo, H. F. J. 2000. Incidence of bean common mosaic virus and bean common mosaic necrosis virus in bean (Phaseolus vulgaris L.) and wild legume seedlots in Tanzania. Seed Sci. Technol. 28:85-92.

Nordenstedt, N., Marcenaro, D., Chilagane, D., Mwaipopo, B., Rajamäki, M.-L., Nchimbi-Msolla, S., Njau, P. J. R., Mbanzibwa, D. R., and Valkonen, J. P. T. 2017. Pathogenic seedborne viruses are rare but Phaseolus vulgaris endornaviruses are common in bean varieties grown in Nicaragua and Tanzania. PLoS One 12:e0178242.

Patil, B. L., and Kumar, P. L. 2015. Pigeonpea sterility mosaic virus: a legumeinfecting emaravirus from South Asia. Mol. Plant Pathol. 16:775-786.

Prendeville, H. R., Ye, X., Morris, T. J., and Pilson, D. 2012. Virus infections in wild plant populations are both frequent and often unapparent. Am. J. Bot. 99:1033-1042.

Revers, F., and Garcia, J. A. 2015. Molecular biology of potyviruses. Adv Virus Res. 92:101-199.

Rey, M. E. C., Ndunguru, J., Berrie, L. C., Paximadis, M., Berry, S., Cossa, N., Nuaila, V. N., Mabasa, K. G., Abraham, N., Rybicki, E. P., Martin, D. Pietersen, G., and Esterhuizen, L. L. 2012. Diversity of dicotyledenous-infecting geminiviruses and their associated DNA molecules in Southern Africa, including the South-West Indian Ocean Islands. Viruses 4:1753-1791.

Rosen, R., Kanakala, S., Kliot, A., Pakkianathan, B. C., Farich, B. A. Santana-Magal, N., Elimelech, M., Kontsedalov, S., Lebedev, G., Cilia, M. and Ghanim, M. 2015. Persistent, circulative, transmission of begomoviruses by whitefly vectors. Curr. Opin. Virol. 15:1-8.

Rwegasira, G. M., and Chrissie, M. E. R. 2015. Efficiency of non-vector methods of cassava brown streak virus transmission to susceptible cassava plants. Afr. J. Food Agric. Nutr. Dev. 15:10336-10351.

Segundo, E., Carmona, M. P., Sáez, E., Velasco, L., Martín, G., Ruiz, L., Janssen, D., and Cuadrado, I. M. 2008. Occurrence and incidence of viruses infecting green beans in South-Eastern Spain. Eur. J. Plant Pathol. 122:579-591.

Sengooba, T. N., Spence, N. J., Walkey, D. G. A., Allen, D. J., and Lana, A. F. 1997. The occurrence of bean common mosaic necrosis virus in wild and forage legumes in Uganda. Plant Pathol. 46:95-103.

Sivparsad, B. J., and Gubba, A. 2013. Identification and distribution of viruses infecting sweet potato (Ipomoea batatas L.) in KwaZulu-Natal province, South Africa. S. Afr. J. Plant Soil 30:179-190.

Spence, N. J., and Walkey, D. G. A. 1995. Variation of pathogenicity among isolates of Bean common mosaic virus in Africa and reinterpretation of the 
genetic relationship between cultivars of Phaseolus vulgaris and pathotypes of BCMV. Plant Pathol. 44:527-546.

Susi, H., Filloux, D., Frilander, M. J., Roumagnac, P., and Laine, A.-L. 2019. Diverse and variable virus communities in wild plant populations revealed by metagenomic tools. PeerJ 7:e6140.

Sydänmetsä, M., and Mbanzibwa, D. R. 2016. Occurrence of Cucumber mosaic virus, Zucchini yellow mosaic virus and Watermelon mosaic virus in cultivated and wild cucurbits in the coastal areas of Tanzania. Afr. J. Agric. Res. 40:4062-4069.

Tugume, A. K., Mukasa, S. B., and Valkonen, J. P. T. 2008. Natural wild hosts of Sweet potato feathery mottle virus show spatial differences in virus incidence and virus-like diseases in Uganda. Phytopathology 98:640-652.

Untiveros, M., Fuentes, S., and Salazar, L. F. 2007. Synergistic interaction of Sweet potato chlorotic stunt virus (Crinivirus) with carla-, cucumo-, ipomo-, and potyviruses infecting sweet potato. Plant Dis. 91:669-676.
Vetten, H. J., and Allen, D. J. 1991. Recent progress in the identification of viruses of Phaseolus vulgaris in Africa. Pages 3-4 in: Annu. Rep. Bean Improv. Coop. Natl. Dry Bean Counc. Res. Conf. USDA National Agricultural Library. http:// handle.nal.usda.gov/10113/IND91054045

Worrall, E. A., Wamonje, F. O., Mukeshimana, G., Harvey, J. J., Carr, J. P., and Mitter, N. 2015. Bean common mosaic virus and bean common mosaic necrosis virus: relationships, biology, and prospects for control. Adv. Virus Res. 93:1-46.

Yarwood, C. E. 1957. Mechanical transmission of plant viruses. Adv. Virus Res. 4:243-278.

Zheng, Y., Gao, S., Padmanabhan, C., Li, R., Galvez, M., Gutierrez, D. Fuentes, S., Ling, K. S., Kreuze, J., and Fei, Z. 2017. VirusDetect: An automated pipeline for efficient virus discovery using deep sequencing of small RNAs. Virology 500:130-138.

Zitter, T. A., and Murphy, J. F. 2009. Cucumber mosaic. The Plant Health Instructor, 10:516-518. doi:10.1094/PHI-I-2009-0518-01. 